\title{
PENGARUH MODEL PROBLEM BASED LEARNING TERHADAP HASIL BELAJAR SISWA PADA MATERI POKOK SUHU DAN KALOR DI KELAS X SEMESTER II SMA NEGERI 20 MEDAN T.P. 2015/2016
}

\author{
Adelyna Oktavia Nst dan Rahmatsyah \\ Jurusan Fisika FMIPA Universitas Negeri Medan \\ Jalan Willem Iskandar Pasar V Medan, Sumatera Utara \\ adelynaoktavia46@gmail.com
}

\begin{abstract}
ABSTRAK
Penelitian ini bertujuan untuk mengetahui apakah hasil belajar dengan menggunakan model Problem Based Learning lebih baik dari pada model pembelajaran konvensional pada materi pokok Suhu dan Kalor kelas X SMA Negeri 20 Medan T.P 2015/2016. Populasi dalam penelitian ini adalah seluruh siswa kelas X Semester II SMA Negeri 20 Medan yang terdiri dari tiga kelas. Sampel penelitian ini diambil dua kelas yaitu kelas X-IPA1 sebagai kelas eksperimen dan kelas X-IPA2 sebagai kelas kontrol yang masingmasing berjumlah 31 siswa yang ditentukan dengan teknik cluster random sampling. Kedua kelas diberikan perlakuan yang berbeda, kelas eksperimen dengan model problem based learning dan kelas kontrol dengan pembelajaran konvensional. Data yang digunakan dalam penelitian ini digunakan tes essay, jumlah soal 10 item yang telah divalidkan oleh validator. Berdasarkan hasil penelitian diperoleh nilai rata-rata pretes kelas eksperimen dan kelas kontrol memiliki kemampualan awal yang sama. Kelas eksperimen aktivitas belajar siswa dengan model problem based learning pada materi pokok suhu dan kalor di kelas X SMA Negeri 20 Medan T.P.2015/2016 meningkat setelah pembelajaran selesai diberikan postes. Berdasarkan hasil uji $\mathrm{t}$ diperoleh $t_{\text {hitung }}>t_{\text {tabel }}$ sehingga $H_{a}$ diterima. Melalui uji $t$ tersebut diperoleh hasil signifikan hasil belajar dengan menggunakan model problem based learning. Hasil belajar siswa menggunakan model problem based learning lebih tinggi daripada hasil belajar siswa dengan menggunakan pembelajaran konvensional pada materi pokok suhu dan kalor di SMA Negeri 20 Medan.
\end{abstract}

Kata kunci: quasi eksperimen, problem based learning, konvensional

\section{ABSTRACT}

This research aims to find out if the results of a study using Problem Based Learning model is better than the conventional model of learning in subject matter and Heat Temperature class X SMA Negeri 8 Medan t. P 2015/2016. The population in this research is the whole grade X Semester II SMA Negeri 8 Medan consisting of three classes. This research sample taken two classes, namely class X-IPAl as class experiments and X-class as a class that controls IPA2 respectively amounted to 31 students determined by Cluster Random Sampling techniques. Then be given different treatment, class experiments with models of problem based learning and classroom learning with conventional controls. The data used in this study used a test essay, the number of reserved 10 items that have been divalidkan by the validator. Of research results obtained average value of experimental class and class pretes controls have the same initial kemampualan. On a class of experimental learning activities of students 
with models of problem based learning in the subject matter and heat temperature in class X SMA Negeri 8 Medan T.P. 2015/2016 increases after learning done given postes. From the test results obtained thitung > ttabel $t$ so Ha. Through the t-test results of significant learning results obtained by using the model of problem based learning. Thus, that the results of student learning using problem based learning model is higher than on the results of student learning by using conventional learning model on heat and temperature of a subject matter in SMA Negeri 8 Medan.

Keywords: Quasi experiments, Problem Based Learning, conventional

\section{PENDAHULUAN}

Permendikbud Republik Indonesia Nomor 69 Tahun 2013 Tentang Standar Isi Kurikulum 2013, pada rumusan Kompetensi Inti 3 (KI 3) pendidikan menengah di kelas X SMA disebutkan bahwa dalam pembelajaran diharapkan peserta didik mampu memahami dan menerapkan pengetahuan faktual, konseptual, prosedural dalam pengetahuan, teknologi, seni budaya, dan humaniora dengan wawasan kemanusiaan, kebangsaan, kenegaraan, dan peradaban terkait fenomena, ilmiah dan kejadian, serta menerapkan pengetahuan prosedural pada bidang kajian yang spesifik sesuai dengan bakat dan minatnya untuk memecahkan masalah. Pergeseran paradigma pembelajaran abad 21 mengarahkan bahwa dalam pembelajaran hendaknya mendorong peserta didik mencari tahu bukan diberi tahu, mencari tahu dengan berbagai kegiatan pembelajaran antara lain mengamati, menanya, mengumpulkan data, mengasosiasi, mengkomunikasikan (Nulaili, 2013). Kondisi pembelajaran seperti inilah yang mengakibatkan kurang terbukanya wawasan pengetahuan, sikap, dan perilaku siswa, sehingga pembelajaran yang dilakukan kurang efektif. Seperti yang diungkap oleh Mardana (2004) bahwa pembelajaran fisika pada umumnya masih dipandang sebagai pelajaran yang sulit, karena kemasan pembelajaran kurang menarik.

Fisika pada hakikatnya sebagai kumpulan pengetahuan yang dapat berupa fakta, konsep, prinsip, hukum, teori, dan model yang biasa disebut produk. Selain itu, yang paling penting dalam fisika adalah penemuan melalui proses pencarian dengan tindakan nyata. Dalam proses pembelajaran, siswa kurang didorong untuk mengembangkan kemampuan berpikir. Proses pembelajaran di kelas diarahkan kepada kemampuan anak untuk menghafal informasi. Otak anak dipaksa untuk mengingat dan menimbun berbagai informasi tanpa dituntut memahami informasi yang diingatnya itu untuk menghubungkan dengan kehidupan seharihari. Akibatnya, ketika anak didik lulus dari sekolah, anak didik tersebut pintar teoritis, tetapi miskin aplikasi (Sanjaya, 2011).

Kenyataan tersebut tampak berdasarkan hasil studi pendahuluan yang dilakukan di SMA N 20 Medan dengan melakukan wawancara kepada guru fisika, diperoleh data ujian akhir mata pelajar fisika siswa yang pada umumnya masih rendah yaitu nilai rata-rata 65-70 sedangkan kriteria ketuntasan minial (KKM) yang akan dicapai adalah 70. Sehingga dapat dikatakan nilai rata-rata siswa tidak mencapai kriteria ketuntasan minimal yang diharapkan. Hal ini relevan dengan data yang diperoleh dari angket yang diberikan kepada 30 orang siswa. Sebanyak 46,6\% (14 orang siswa) berpendapat fisika adalah pelajaran yang disukai, mudah, menyenangkan, dan mudah dipahami, 50\% (15 orang siswa) berpendapat fisika adalah pelajaran yang tidak disukai, sulit dipahami dan kurang menarik. Hasil penelitian menunjukkan bahwa menggunakan Problem Based Learning mempromosikan 
pemahaman lebih baik daripada menggunakan pembelajaran konvensional antara mahasiswa fisika di Irak (Zain, 2014)

Model Problem Based Learning sudah pernah diteliti oleh beberapa peneliti sebelumnya diantaranya Dwi, dkk (2013) setelah dilakukan perlakukan berbeda pada kelas eksperimen dan kontrol, terdapat perbedaan pemahaman konsep yang signifikan antara siswa yang dibelajarkan dengan menggunakan Model pembelajaran berbasis masalah berbantuan ICT dengan Model pembelajaran berbasis masalah. Peneliti selanjutnya Annovasho dan Budiningarti (2014) hasil yang diperoleh adalah pada ranah kognitif mengalami peningkatan dengan dengan rata-rata nilai 65,79, dan Hamdani, dkk (2015) pembelajaran berbasis masalah dapat meningkatkan hasil belajar siswa hal ini dapat terlihat dari hasil belajar siswa meningkat untuk setiap siklus, baik dari aspek afektif, psikomotorik dan kognitif. Hasil yang diperoleh yakni dari nilai ratrata aspek kognitif pada siklus I $(67,74)$, siklus II $(82,88)$ dan siklus III $(76,03)$.

\section{METODE PENELITIAN}

Penelitian ini dilaksanakan di SMA Negeri 20 Medan. Waktu penelitian ini akan diadakan pada semester II T.P 2015/2016.

Sampel dalam penelitian terdiri dari dua kelas yaitu kelas kontrol dan kelas eksperimen yang diambil dengan teknik cluster random sampling. Satu kelas dijadikan sebagai kelas eksperimen yaitu kelas yang diajar melalui model Problem Based Learning dan satu kelas lagi dijadikan sebagai kelas kontrol yaitu kelas yang diajar melalui pembelajaran konvensional.

Tes hasil belajar terlebih dahulu distandarisasi dengan dua orang dosen dan satu guru sesuai dengan pakar ahlinya. Setelah data pretes diperoleh,dilakukan analisis data dengan uji normalitas dengan uji liliefors dan uji homogenitas uji $\mathrm{t}$ dua pihak untuk mengetahui kemampuan awal siswa pada kedua kelompok sampel dalam hal ini kemampuan awal kedua sampel tersebut harus sama. Selanjutnya peneliti mengajarkan materi menggunakan model problem based learning pada kelas eksperimen dan pembelajaran konvensional pada kelas kontrol. Untuk mengetahui perbedaan hasilakhirnya maka dilakukan postes menggunakan uji tsatu pihak untuk mengetahui pengaruh perlakuan model problem based learning dengan menggunakan terhadap hasil belajar siswa.

\section{HASIL DAN PEMBAHASAN}

Pada awal penelitian, kedua kelas diberikan tes uji kemampuan awal (pretest) yang bertujuan untuk mengetahui apakah kemampuan awal siswa pada kedua kelas sama atau tidak. Berdasarkan data hasil penelitian pada lampiran diperoleh nilai rata-rata pretes siswa pada kelas eksperimen sebelum diberi perlakuan dengan menggunakan Problem Based Learning sebesar 21,38 dengan standar deviasi 7,27 dan di kelas kontrol diperoleh nilai rata-rata pretest siswa sebesar 13,06 dengan standar deviasi 5,84.

Untuk melihat secara rinci hasil pretes kedua kelas dapat dilihat pada Gambar 1.

\section{Gambar 1. Hubungan Pretes Kelas Eksperimen dan Kontrol}

Gambar 1 menunjukkan bahwa nilai pretes pada kelas eksperimen dan kelas kontrol tidak jauh berbeda, artinya kedua kelas mempunyai kemampuan awal yang hampir sama dan perolehan nilai kedua kelas merata.

Sebelum dilakukan uji hipotesis terlebih dahulu dilakukan uji prasyarat data yaitu uji normalitas menggunakan uji Lilliefors. Hasil uji normalitas yang diperoleh adalah Kelas eksperimen $\mathrm{L}_{\text {hitung }}=$ $0,13, \mathrm{~L}_{\text {tabel }}=0,15$. Untuk kelas kontrol $\mathrm{L}_{\text {hitung }}$ $=0,08, \mathrm{~L}_{\text {tabel }}=0,15$. Kesimpulannya kedua kelas berdistribusi normal.

Pengujian homogenitas dilakukan untuk mengetahui apakah kelas sampel berasal dari populasi yang homogen atau 
tidak, artinya apakah sampel yang dipakai dalam penelitian ini dapa mewakili seluruh populasi yang ada.

Pengujian homogenitas data dilakukan dengan uji F. Hasil uji homogenitas data yang diperoleh adalah $\mathrm{F}_{\text {hitung }}<\mathrm{F}_{\text {tabel }}=1,55<1,84$. Nilai $\mathrm{F}_{\text {hitung }}<\mathrm{F}_{\text {tabel }}$ yang berarti bahwa sampel yang digunakan dalam penelitian ini dinyatakan homogen atau dapat mewakili seluruh populasi yang ada.

Setelah kedua kelas diberikan perlakuan yang berbeda, kedua kelas selanjutnya diberikan postes dengan soal yang sama seperti soal pretes yang bertujuan untuk mengetahui hasil belajar siswa. Berdasarkan data hasil penelitian diperoleh nilai rata-rata postes siswa pada kelas eksperimen setelah diberi perlakuan dengan menggunakan model Problem Based Learning sebesar 71,96 dengan standar deviasi 5,33 dan di kelas kontrol diperoleh nilai rata-rata postest siswa sebesar 68,93 dengan standar deviasi 6,81. Untuk melihat secara rinci hasil protes kedua kelas dapat dilihat pada Gambar 2.

\section{Gambar 2. Perbandingan Nilai Postest Kelas Eksperimen dan Kontrol}

Gambar 2 menunjukkan bahwa pada kelas eksperimen, nilai yang dicapai oleh siswa lebih merata dibandingkan pada kelas kontrol. Hal ini menunjukkan bahwa penerapan model Problem Based Learning baik untuk dilakukan.

Berdasarkan hasil uji hipotesis diperoleh $t_{\text {hitung }}>t_{\text {tabel }}=5,77>1,67$. Dalam hal ini dapat disimpulkan bahwa hasil belajar siswa pada kelas eksperimen lebih besar dari hasil belajar kelas kontrol, berarti ada pengaruh yang signifikan akibat model Problem Based Learning terhadap hasil belajar pada materi pokok Suhu dan Kalor di kelas X SMA Negeri 20 Medan T.P 2015/2016.

\section{KESIMPULAN}

1. Pembelajaran dengan model Problem Based Learning pada materi pokok suhu dan kalor sebelum diberikan perlakuan rata-rata pretes siswa sebesar 21,38 dan setelah diberikan perlakuan rata-rata postest siswa sebesar 71,96.

2. Aktifitas belajar siswa dengan model Problem Based Learning pada materi pokok suhu dan kalor mengalami peningkatan. Pada pertemuan I nilai 48,00 dengan katagori cukup aktif, pertemuan II nilai 57,80 dengan katagori cukup aktif, pertemuan III nilai 76,60 dengan katagori aktif.

3. Ada pengaruh model Problem Based Learning terhadap hasil belajar siswa pada materi pokok suhu dan kalor dengan $t_{\text {hitung }}>t_{\text {tabel }}=5,89>1,93$ pada taraf signifikan

\section{DAFTAR PUSTAKA}

Annovasho, J. dan Budiningarti, H., (2014), Pengaruh model pembelajaran Berdasarkan masalah terhadap hasil belajar siswa kelas $\mathrm{X}$ peminatan MIPA pada pelajaran Fisika Materi Suhu dan Kalor di SMA Negeri 1 Baureno Bojonegoro, Jurnal Inovasi Pendidikan Fisika 03: 20-26.

Dwi, I. M,. Arif, H., dan Sentot, K., (2013), Pengaruh Strategi Problem Based Learning Berbasis ICT terhadap pemahaman konsep dan kemampuan pemecahan Masalah Fisika , Jurnal Pendidikan Fisika Indonesia 09: 817.

Hamdani, D., Prasetya, D. A., dan Connie., (2015), Penerapan Model Problem Based Learning (PBL) dengan metode eksperimen untuk meningkatkan aktivitas dan hasil belajar IPA-Fisika siswa kelas VIII.A 12 Kota Bengkulu, Prosiding seminar Nasional Fisika (e-journal) 04.

Mardana, I. B., (2004), Penerapan Strategi Pembelajaran Pengubah Miskonsepsi dengan Model Simulasi Computer Berorientasi Konstruktivisme untuk Meningkatkan Minat, Hasil Belajar, dan Literasi Komputer Siswa, 
Jurnal Pendidikan dan Pengajaran IKIP Negeri Singaraja, IKIPN Singaraja.

Nulaili, (2013), Kurikulum 2013 dan Implementaasinya di SMA, Kementerian Pendidikan dan Kebudayaan, Jakarta.
Sanjaya, W., (2011), Strategi Pembelajaran Berorientasi Standar Proses Pendidikan, Penerbit Kencana Prenada Media Group, Jakarta Zain, A. N. (2014), The impact of PBL on Undergraduate Physics. 